\title{
"They have no taste in Morocco." Home furnishing, belonging, and notions of religious (im)perfection among white Dutch and Flemish converts in Morocco
}

\author{
Nina ter Laan ${ }^{1,2}$
}

Accepted: 27 December 2020/ Published online: 13 May 2021

(C) The Author(s) 2021

\begin{abstract}
This article focuses on furnishing practices in the domestic space of the homes of white Flemish and Dutch Muslim female converts to Islam who made hijra (Islamic migration) to Morocco. Fed up with European Islamophobia and longing for a place that supports and strengthens their faith, they decided to emigrate to a Muslim country. However, remarkably, once settled in Morocco, many experience discontent with regard to a perceived "lack of true Islam" in the country. To gain insight into the positions and experiences of these women, I look at how they create a sense of belonging through furnishing practices in the domestic space of their new homes. I am interested in how various senses of belonging are expressed and come together in relation to their construction of religious belonging and place, and are renegotiated through domestic decoration practices. Building on literature on home, transnational migration, conversion, and material religion, I demonstrate that mechanisms of distinction and notions of religious (im)perfection intersect in the organization of the domestic space. Based on ethnographic accounts, I argue that my interlocutors bring a "culturalized" West-European Islam to Morocco, with tastes and sensibilities that jostle uneasily against local Moroccan religious practices but also allows them to repair some of the privileges they lost upon their conversion in their homeland. Lastly, this article shows that it is through the engagement with mundane material forms, but also with absence and empty spaces, that Islam becomes present in their domestic spaces, enhancing the cultivation of their ethical selves.
\end{abstract}

Keywords Morocco $\cdot$ Islam $\cdot$ Migration $\cdot$ Conversion $\cdot$ Home $\cdot$ Material Religion

Nina ter Laan

nterlaan@unikoeln.de

1 Department of Philosophy and Religious Studies, Utrecht University, Utrecht, the Netherlands

2 Department of Social and Cultural Anthropology, University of Cologne, Albertus Magnus Platz, 50923, Cologne, Germany 


\section{Introduction}

Although Morocco is primarily known as a country of emigration delivering Muslims to Europe, over the past ten years, a growing group of European Muslims ${ }^{1}$ has been moving to Morocco. The increasing harsh social and political climate toward Islam and Muslims, together with the longing for a place that supports and strengthens their faith, has caused some of them to set out to make hijra (Islamic migration) to a Muslim country, with some choosing to settle in Morocco. However, remarkably, after their arrival, many experience discontent with regard to a perceived "lack of true Islam" in the country. This ambivalent position toward local religious practices of Moroccan Muslims, poses dilemmas toward their search for religious purity and belonging, and stands at the center of this study.

Both in the media as well as in the literature, Morocco is mainly portrayed as a country people want to leave. Images of desperate young Moroccans climbing high barbwire fences or risking their lives in rickety boats to reach Europe, hoping for a better future, dominate media coverage on Morocco and migration. Most of the scholarly literature on migration also highlights Morocco as a place of emigration. Exceptions are studies of transit migration of sub-Sahara Africans to Morocco (Berriane et al. 2016) and of former so-called guest workers returning from Europe back to Morocco (De Bree et al. 2011). Conversely, studies on hijra mainly focus on young male Muslim men (and sometimes women) who temporarily depart to fight in conflict zones such as Iraq and Syria (Navest et al. 2016; Ubermann \& Shay 2016). These works are mostly framed in a setting of jihad and terrorism, while the presence and experiences of European Muslims in the Middle East is much more diverse (and historically rooted). To date, hijra to Morocco has received scarcely any attention (Kiefer 2019; Vroon \& Moors this issue).

By taking an ethnographic approach, I aim to contribute to a wider and more indepth understanding of hijra, as well as of Morocco as a country of immigration, by focusing on the positions and experiences of white female Muslim converts from Flanders and the Netherlands, ${ }^{2}$ who initiated hijra to Morocco and who self-identify as muhajirat (female migrants). Besides their motivations to take this step, I concentrate on the day-to-day resources they mobilize to try and feel at home in their new environment. To do this I take their homemaking practices as a central focus, and especially the furnishing of the domestic space. What do these furnishing practices, such as the organization of images and objects, express regarding their sense of belonging?

I build on existing literature about conversion to Islam, home and belonging, transnational migration, and material religion. Building on Bourdieu's theory of distinction (Bourdieu 1984), I explore the tastes and preferences of Dutch and Flemish muhajirat who have settled in Morocco, by ethnographically exploring their narratives,

\footnotetext{
${ }^{1}$ As European countries do not register religious denomination, it is hard to say how many European Muslims have been leaving Europe for the purpose of hijra. Also, many migrants stay registered citizens in their home country after they make hijra.

${ }^{2}$ I selected this particular group because in the course of my field-research, I discovered that within the group of European Muslims who made hijra to Morocco, common nationality, but also a shared language strongly marks and influences the formation of social relations and a sense of group belonging. My own Dutch background and my experience with having lived in Morocco helped in connecting with these women on multiple levels.
} 
practices, and ethical deliberations of furnishing the domestic space of their homes. As this study accentuates from an anthropological perspective the material sensibilities of everyday life, I also connect to the ongoing debate on piety versus "everyday Islam" (Deeb 2015; Fadil and Fernando 2015; Schielke 2010).

My analysis of the ethnographic accounts demonstrates how the domestic space serves as an important arena for women to highlight and negotiate different aspects of their identities, as well as to cultivate an ethical self. The women in my research try to create a Muslim atmosphere in their homes through the careful selection and arrangement of images and objects. These furnishing practices and artifacts not only serve as idioms to mark their embodied presence in Morocco but also reveal mechanisms of distinction that intersect with notions of religious (im)perfection. In so doing, I argue that my interlocutors bring a "culturalized" West-European Islam to Morocco, that jostles uneasily against local Moroccan religious sensibilities, but also allows them to repair some of the privileges they lost upon their conversion in their homeland. Another main point is to show that it is through the engagement with mundane material forms, but also with "immaterial" forms, such as open spaces and nonappearance, that a religious atmosphere is generated in their domestic spaces, providing the setting for the formation of an ethical self.

The article is part of my ethnographic study regarding homemaking practices among Dutch-speaking female Muslim converts with Belgian and Dutch nationalities, who have performed hijra to Morocco. The material presented is based on six months of ethnographic fieldwork I conducted between 2015 and 2018 in different cities in Morocco. I carried out semi-structured in-depth interviews and informal conversations, as well as participant observation through visits in the homes of 16 Dutch and Flemish female Muslims (13 converted, 3 born $)^{3}$ residing in Morocco. I also lived in the homes of two converted Muslim families (one Dutch, one Flemish) during the summer months of 2018. Both in and outside Morocco, I maintained contact with them through social media and email. For the sake of the privacy and protection of my interlocutors, I changed their real names and left out any personal information that could be traced back to my actual interlocutors.

The article consists of six sections. I first describe the contextual background, in which I address islamophobia and conversion to Islam, needed to understand the emigration of my interlocutors to Morocco. I then present an ethnographic vignette from my fieldwork, which is exemplary of the narratives and practices of home furnishing I describe. After the vignette, I introduce my theoretical lens of home, migration, and material religion, followed by the empirical material on my interlocutors' incentives to move to Morocco, their experiences of their lives there, and their practices and narratives of furnishing their domestic interior. After the analysis of the ethnographic material, I present some concluding remarks.

\section{Islamophobia and conversion to Islam}

The religious emigration of Dutch and Flemish Muslim female converts to Morocco is a relatively recent phenomenon. It is also part of two broader

\footnotetext{
${ }^{3}$ I have spoken to male and female muhajirun from both groups. A comparison of the experiences and positions between both groups is part of my broader project, but for the sake of focus and space, I concentrate primarily on white converted women in this article.
} 
developments I discuss in the following section: the rise of Islamophobia in Europe and conversion to Islam.

Negative attitudes, stereotyping, and discrimination regarding Muslims and Islam in "the West" has a long history (Said 1978). However, Islamophobic discourses only gained wider acceptance in the 1980s, parallel to racist and emerging anti-migrant sentiments (De Koning 2019: 7). The term Islamophobia itself entered contemporary debates with the publishing of a report by a British NGO in $1997,{ }^{4}$ that highlighted prevalent Islamophobia in the UK. Since then, the term has been adopted by the media, politics, citizens (Muslim and non-Muslim), as well as academia (Bleich 2011). After 9/11, Muslims and Islam around the world became associated with violent extremism, leaving a large impact on Islamophobic discourses toward Islam and Muslims in Europe. An anti-migrant fervor spread further, as well as a right-wing populist rhetoric of Europe becoming Islamized and engulfed by Muslims, who are perceived an alleged risk to security and supposedly at odds with "Western" modern liberal values of secular society (Berger 2014; Fadil 2014; De Koning 2016b; Meyer 2018; Moors 2009).

As a result, in current public debates, media representations, politics, and everyday behavior, the presence of Muslims and the material manifestations of Islam in public (such as mosques, Islamic dress, halal food) is continuously questioned and problematized, despite the legal principle of equality and freedom of religion in the constitution of European countries (Meyer 2018: 70). In these discourses, old colonial and racist stereotypes are invoked, in which Muslims are portrayed as foreign, nonwhite, inferior, backward, and failing to adopt modern secular freedoms (De Koning 2016b: 191; Mitiche 2019). As a consequence, a diverse group of European citizens is framed as a separate category of "Muslims" and Muslim-like people. This is what Martijn de Koning refers to as "the racialization of Muslims," which: "interpellates Muslims as an exceptional and unacceptable 'Other' based upon ideas about culture, descent, and liberal values” (de Koning 2016a: 171).

Anxieties surrounding Islam also affect converts to Islam. Conversion to Islam by white people in contexts where Islam has been racialized as "non-white" is hardly accepted in mainstream European societies and sometimes regarded as incompatible, or questioning the idea of white people as secular and modern (Özyürek 2015; Van Es 2019). Consequently, white converts to Islam become racialized as Muslim and hence categorized as non-native. According to Moosavi, they even lose their white privilege, as converted Muslims become associated with immigrant Muslims and face similar stigmatization (Moosavi 2015). Especially white women who wear the hijab in public, and thus are visibly Muslim, are targets of discrimination (Noor 2018; Van Nieuwkerk 2004, van Nieuwkerk 2006; Vroon-Najem 2014). The converts, however, continue to see themselves as Dutch or Flemish and do not identify as, nor fit into ethnic Muslim communities. The loss of their previously held and taken-for-granted social status and privileges, due to their conversion, makes Islamophobia hard to digest and comes with a painful struggle for gaining acceptance and belonging as white Muslims in their own society.

Several scholars have analyzed how the symbolic breaching of the taken-for-granted and assumed antithetical positions of being both white and Muslim are dealt with by

\footnotetext{
${ }^{4}$ Islamophobia a Challenge for Us All: Report of the Runnymede Commission on British Muslims and Islamophobia (1997).
} 
white converts (Galonnier 2015; Noor 2018; Özyürek 2015; Rogozen-Soltar 2012; Vroon 2014). This ranges from converts proving they are still "normal" and "emancipated" women (Van Es 2019: 11), to converts distancing themselves from certain Muslims with a migration background, viewing their Islam as polluted by cultural traditions that have little to do with "true Islam." Instead, they strive toward an Islam, imagined as purified from culture and local traditions, emphasizing the universalistic appeal of Islam (Özyürek 2015; Galonnier 2015: 25). While a number of Muslims attempt to resist the racialization of Muslims (De Koning 2008; de Koning 2016a; de Koning 2016b; Roex et al. 2010; Van Es 2019), some Muslims refuse to engage in this debate at all. Instead of trying to fight stereotypes and gaining acceptance from their own mainstream society, they detach themselves (Olsson 2014) and may even decide to set out to make hijra. This group stands central in this article.

Few studies on conversion (Rogozen-Soltar 2012; Vroon 2014; Noor 2018; Özyürek 2015) mention hijra. The prevalence of the desire to emigrate to a Muslim majority country among converts is noted by Vanessa Vroon-Najem. In her work on Dutch women converting to Islam, she mentions the distress converts experience of suddenly being considered a minority after their conversion, as well as their wish to emigrate to a Muslim majority country (Vroon 2014: 127). However, the studies mentioned focus on countries in which Muslims are a minority. Scarcely any longterm ethnographic fieldwork has been conducted among converts from European countries who have actually emigrated to a Muslim-majority country. What happens to their positionality when these "white" Muslims emigrate to a country such as Morocco? My study aims to answer this question, by examining how the "whiteness" of these women evolves in the context of hijra to Morocco, a country with a colonial past and different racial hierarchies.

\section{Cushions with or without fringes?}

In the summer of 2017, I visited one of my interlocutors in her new home. I got to know Tanja in 2011, when I first met her in Morocco through a mutual friend. Tanja who was now in her late thirties, is married to Hussein with whom she has five children. She is originally from the North of the Netherlands, and has lived in Morocco for 12 years. She converted to Islam in the Netherlands where she also met and married her husband Hussein, a son of a Moroccan guest worker family from the northern Rif region. They gradually evolved toward a Salafi orientation. After the birth of their first child, Tanja and her husband decided to perform hijra: the religious-inspired migration to a Muslim country. They chose to go to Morocco, as they got the opportunity to help set up a primary school based on a strict interpretation of the Sunna. After their move, Tanja's husband made several attempts to start his own business, which became quite lucrative after a couple of years. Tanja took care of their home and children. This gave them the opportunity to relocate from their first modest apartment in the city center to a large house in the suburbs. During all the visits I paid to Tanja, time and again I was warmly received by her and her children.

At my most recent visit, she received me in the lounge of their residence. I noticed she had redecorated the interior a bit. I complimented her on her seddari (long Moroccan sofas against the walls), and how the beige-brown fabric matched the 
curtains and the colors of the walls very well. "Yes" she responded, "but it was a lot of work to get it all right. They have no taste in Morocco and they do everything according to these little silly rules. Take, for instance, the fringes on the cushions of the couch. Somehow people here think that cushions always need to have fringes, but I think it's awful. It's very hard to convince people that it is also possible to have cushions without fringes." She then told me a related story about a friend (another Dutch convert living in Morocco) who recently ordered cushions without fringes at a textile shop, but the upholsterer resisted her idea firmly. "Without fringes?" she had said to Tanja's friend; "how could this be? Was she out of her mind?" Her friend told the upholsterer she was the one paying, so she had to follow her order. "The customer is always right, don't you think?" Tanja said. Tanja's friend pushed her request through, and when her order was ready, the lady of the fabric shop was so thrilled about the result, she even took pictures of the fringeless cushions for the shop's presentation folder. Tanja then complains about how another fabric shop, she had engaged, added many unasked-for elements to the mattresses and cushions she had commanded: "They applied this hideous leather ridge to the mattresses of the seddari, and it is even fake leather!" I told her that I do not see any leather ridges, but she showed me the ridges. She had put the mattresses in such a way that the leather ridges were turned towards the backside, so that no one could see them. She explained: "the upholsterer also switched the fabrics of the upper and lower mattress, and without consulting me made fringes to the cushions."

\section{A material approach to transnational homemaking practices and religion}

I theorize Dutch and Flemish muhajirat leaving their country of residence to settle in a Muslim country within a theoretical framework of home, transnational migration, and material religion. First, I use the concept of "home" as a tool to understand my interlocutors' incentives to make hijra to Morocco, as well as to analyze their narratives and practices of furnishing the domestic space of their homes. Home is a multifaceted concept, with a wide variation of interrelated meanings, involving material, bodily, social, and political dimensions. "Home" can refer to a physical, built structure where people dwell, but it can also indicate broader feelings of belonging, whether in terms of a community, neighborhood, a city, a cultural identity, or a nation (Massey 2005, Jansen and Löfving 2009; Mallet 2004: 64). Home as a paradigm of belonging consequently implicates mechanisms of inclusion and exclusion, and thus can turn into a field of political contestation over loyalties and (national) identities, such as has been described in literature on the culturalization and emotionalization of citizenship (Duyvendak 2011; Nowicka 2007; Yuval-Davis 2011; Hooks 2009; Schinkel 2008).

In addition, a bounded place of dwelling or a broader sense of belonging, home is also a process of creating and "negotiating a sense of home vis-a-vis its external circumstances" (Boccagni 2017: 3). ${ }^{5}$ As stated by Duyvendak, "home" lies not so much in the effect of the physical place, but is more the result of "home-making practices." While "house" refers to the physical built structure, "home" refers to a space

\footnotetext{
5 This process is what Paolo Boccagni calls "homing" (Boccagni 2017)
} 
that is lived; where activities take place, identities are expressed, and socio-cultural meanings are constructed (Jackson 1995: 148; Mallet 2004: 95). Home-making practices - a wide range of activities connected to the everyday organization of a household, such as food practices, cleaning, taking care of relatives, as well as home furnishing - not only reflect but also reproduce and develop cultural traditions and identities, next to steering particular social interactions. Homemaking practices can thus also become part of various strategies of reconfiguring and appropriating an alien space to try and feel at home (Duyvendak 2011: 31-32). As homemaking practices create meaning and attachment to a physical environment, it can also be seen as a practice of place-making (Jaffe and Koning 2016: 25; Sandu 2013: 500).

Practices of homemaking have been widely studied in the context of transnational migration and mobility. These studies demonstrated that home is not fixed in time and space, but can be transferred and imagined (Appadurai 1996; Bhabha 1994; Hall 1990; Wilson and Dissanayake 1996). Through practices of homemaking, transnational migrants symbolically and affectively make reference to different locations and times (such as a nostalgic past or an idealized future) as well as to various aspects of their identity (national, cultural, and religious) in a new unknown environment (Bilecen 2017: 77; Duyvendak 2011: 3).

A material take on home and homemaking has been shown to be a valuable entry point to comprehend the complex entanglements of relationships between people, time and space, and multiple identity aspects involved (Miller 1988). After all, houses are turned into homes, not only through social relations and routines but also through material arrangements (Samanani and Lenhard 2019). Houses are by definition material structures but also need materiality to vest the space with emotion (Ghage 1997; Miller 1988). A material approach to home is thus also closely tied to the senses. Furniture, curtains, carpets, nick-knacks, textures, fabrics, textiles, ceramics, wood and stone, are examples of mundane material elements that infuse the space with particular feelings and sensorial experiences. Certain objects, images, notes, patterns and forms, may trigger feelings of nostalgia or homesickness, or future aspirations. I apply a material approach to my study of home and belonging among Flemish and Dutch muhaijirat residing in Morocco, by focusing on furnishing practices (that is, interior design, domestic decoration, organization of objects and images) in the domestic space of their homes.

In studies of home and migration, the domestic space has shown to be a particular interesting entry-point to gain insight into the expression and formation of feelings of belonging and the (re) construction of one's self in a context of mobility (Boccagni 2014; Dibbits and van der Horst 2007; Young 2005). Irene Cieraad defines the domestic space as "a household's living space within an enclosed structure of a house" (Cieraad 2017: 1). The domestic space indeed entails a very intimate private space, yet it also engages with different degrees of outside influences of both local and global forces (Jaffe and Koning 2016: 30). The design of the domestic space, the materials used, as well as the objects and images there, incorporate socio-cultural ideas about family life, privacy, and leisure (Jaffe and Koning 2016: 31), but also interactions with landlords, neighbors, local retailers, international transport services, and local handymans.

Studies on homemaking practices have shown that various senses of belonging are expressed and shaped in the furnishing practices of domestic spaces. Preferences for a certain style of interior design can reflect wealth and class aspirations, as pointed out by 
Daniel Miller (1988), or express and reproduce class distinction, as revealed by Pierre Bourdieu (1984). However, in my research setting, the material practices of homemaking are not only shaped by social and cultural belonging and migration but also by religious dimensions. Religions can give people a sense of identity and belonging, and they can influence their perception of and desire for the ideal home in which to dwell (De Caigny 2005; Mallet 2004: 67; Tweed 2006). I want to analyze my interlocutors' furnishing practices of their domestic spaces in a context of hijra, through the specific lens of material religion. Such a perspective allows the examination of (the belief in) transcendent realities and spiritual beings (such as angels or demons) as an inherent part of the material entanglements between houses, objects, and people. To include this dimension in the analysis of my ethnographic material, I use the work of scholars of religion who have put materiality at the center of the study of religion (Keane 2008; Meyer 2010, 2012, 2018; Morgan 2010). These involve, among other things, studies on home altars, domestic shrines, and household deities (Gould 2019; Margry 2011; Nelson 2008). These studies primarily show how sacred religious artifacts mark the domestic space as religious and insert the interior with a consecrated atmosphere, but they leave out a context of migration and mobility.

Few studies have focused on the specific intersection of home, transnational migration, and religion. The most important contribution in this theoretical field is made by anthropologist of religion, Thomas Tweed, who discusses the significance of domestic interiors for religious orientation in a context of movement and boundedness, which he calls "crossing and dwelling." He states: "Domestic spaces and practices reciprocally interact with culturally constructed images of the society and the cosmos" (Tweed 2006: 105). He calls this interaction "the kinetics of homemaking" where material culture such as artifacts provide "clues about how these express but also actively shape attitudes about religion and place" (Tweed 1997: 6). Although Tweed's work does not focus on Islam, his angle on the active influence of materiality on inner religious attitudes, resonates with the Foucauldian approach of disciplinary "techniques of the body" as a way to develop the self into a desired state, as used in studies on Muslim piety (Deeb 2006; Hirschkind 2006; Mahmood 2005). These studies, however, focused more on corporeal performances and the relationship between comportment and personal inner dispositions, but less so on material culture as a tool to enhance piety. Studies that pay attention to Islam and materiality, mainly focus on material manifestations of Islam in the public sphere (such as Islamic dress, mosques, halal food), but less so in the private domain. With my analysis of the furnishing and decorating practices of the homes of Dutch and Flemish female converts residing in Morocco, I aim to call attention to this so far unduly neglected dimension. However, before I present my ethnographic material on the interior of their homes, I first discuss how the concept of hijra plays a role in their motivation to leave their home country for Morocco.

\section{Emigrating to Morocco for the purpose of hijra}

When my interlocutors spoke about their migratory experience, they invoked various religious terms, and some particularly mentioned the theological concept 
of hijra. ${ }^{6}$ Those women who refer to their emigration as hijra, would also refer to themselves as muhajirat (f), and told me they followed the advice of certain Muslim scholars who summon practicing Muslims living in the West, to emigrate to a Muslim country. ${ }^{7}$ Such Muslim scholars base their recommendations to make hijra on interpretations of Islamic texts, that describe the migration of the prophet Mohammed (622 A.D.), from Mecca to Medina to escape religious persecution. The women among whom I conducted research told me they followed this advice to move to a Muslim country as to develop their faith (iman), escape fitnah (disorder caused by temptation) in the West, but also to earn credits (hassanat) as to attain a beautiful place in Paradise. In this quest, they strive to practice a "pure" Islam, by emulating and applying the actions and words of the Prophet, as set out in the Quran and the Sunna, as closely as possible into their daily lives (De Koning 2013; Wagenmakers 2016). In this case, if Muslims are in a place where they cannot freely practice their religion, they are supposed to do as Mohammed did, and leave such a place.

Many of my interlocutors applied this reasoning to escape from Islamophobia in their societies of origin. Several women recounted verbal and sometimes physical harassment and discrimination, prior to their departure, as an impetus to leave. Especially women wearing a hijab or more covering garment such as a khimar or niqab recounted stories of intimidation in public. The introduction of legal restrictions on the wearing of face-covering garments in Belgium and the Netherlands, only added to their grievances. ${ }^{8}$ The women told me that all these elements together made them feel oppressed and discriminated as Muslims and they were tired of continuously having to defend their religion and choice to convert. Also, they wanted to spare their children from similar ill-treatment. European Islamophobia is thus interpreted in support of fatwa's advising to relocate from a non-Muslim country to a Muslim country when the practice of their faith is under threat.

Whereas the experience of hostility and discrimination toward Islam and Muslims drove some of these women away from their home country, a longing for acceptance and religious belonging was what drew them toward a Muslim country. For converted muhajirat, the abrupt exclusion they experienced from Dutch or Belgian society, ignited in them a strong desire to be accepted as a Muslim. They were longing to lead a life in an environment where being Muslim is the norm, instead of the exception. For women, for example, it is much easier to cover in public. A Dutch convert living in Rabat told me: "wearing the veil in a Muslim country is more natural. In the

\footnotetext{
${ }^{6}$ Similar theological understandings of mobility and dwelling have been invoked in other types of religiously inspired migration, such as in the Abrahamic notion of "the promised land," the Jewish practice of Aliyah (the immigration to Israel) (Cath 2011), as well as during the emigration of Dutch protestant settlers to North America at the end of the nineteenth century (Swierenga 2000). Such forms of religiously inspired migration, are driven by a sense of persecution and exile, as well as the search for a religious utopic dream. "Home" is then rooted in an imagined and sometimes idealized future place (Ahmed 1999).

${ }^{7}$ Various sorts of oral and written information circulate among my interlocutors on additional conditions and rulings linked to such fatwa's, such as the condition that they have sufficient financial means and the right intention (niyya). Some women in my research even believe making hijra is a religious obligation for all Muslims living in the West.

${ }^{8}$ In Belgium, the wearing of a full-face veil in public has been legally banned entirely since 2011 (www.bbc. com/news/world-europe-14261921). In the Netherlands, a ban on wearing covering face garments in government buildings, schools and on public transport came into effect in the Netherlands in 2019.
} 
Netherlands, you will encounter a lot of resistance."9 They felt happy about the prospect of living in an Islamic ambiance, also referred to by one of my interlocutors as a "Muslim feeling." Not having to worry about halal food, being able to hear the call to prayer five times a day, and to participate fully in Islamic festivities, without feeling like the odd one out, were elements presented as an advantage of living in a Muslim country. This search for a place where being Muslim is the norm, or what I call Muslim normality, ${ }^{10}$ is something which had motivated them to perform hijra.

Their emigration was not only driven by a longing for Muslim normality, but also by a desire for spiritual growth. Based on the assumption in the call to hijra that it is harder to practice the essentials of Islam within a non-Muslim country, running the risk for the corruption of their religion in the current land where they reside in, many women believe it is better for the development of their faith (iman) to reside in a Muslim majority country, instead of the secular societies of their home countries, which they felt formed an obstacle in the practicing of their faith (Jouili 2015). The women in my research come from secular countries with a strong Christian heritage, of which they used to be part. After their conversion to Islam, they were confronted with numerous norms and practices that appeared to be conflicting with Islamic norms, and this made them doubt their ability to preserve and develop their religious identity and that of their families. They believe that living in an environment where it is normal to practice their religion will nurture their spirituality and facilitate the improvement of their iman (faith). Concomitantly, another important incentive indicated by the women was the availability of Islamic schools securing a proper religious education for their children.

The particular choice for Morocco, instead of going to other Muslim countries, is often practical. The main reason my interlocutors indicated in interviews, are the Moroccan roots of their spouses, who in most cases belong to the second and third generation descendants of Moroccan "guest workers," who in the 1960s and 1970s came to Belgium and the Netherlands as temporary laborers (Cottaar, Bouras \& Laouikili, 2009). The networks of their spouses, as well as their familiarity with the country, its language and culture, increases the success rate to build a new life. Also, the developing Moroccan economy offers prospects to make a living: more and more European companies, especially call-centers, with a demand for Dutch and Englishspeaking employees, settle in large Moroccan cities, such as Tangiers, Casablanca, and Rabat. Moreover, compared to the Netherlands or Belgium, the costs of living are relatively low, which allows for a higher standard of living. The short flying distance from Belgium and the Netherlands facilitates traveling between Morocco and the home country. Another asset is the country's geographical proximity to Europe. The three months residence permit, which is automatically issued by the Moroccan state to EU citizens, can be extended by a simple crossing of the border. This circumvents long, complex, and often expensive procedures necessary to attain a permanent residency permit. The Spanish enclaves of Ceuta and Melilla in the north of Morocco facilitate a short passage with the European border even more. Furthermore, Morocco is one of the few politically stable countries of the region and has a pleasant climate. Another reason,

\footnotetext{
${ }^{9}$ Interview with Saskia. Rabat, 10 August 2015.

${ }^{10}$ The concept of "Muslim normality" resonates with the notion of "right to indifference," which Fernando coined (2014: 70). She used this term to describe the longing her Muslim interlocutors in France expressed, to be treated in a more equal and banal way, by calling on the principle of égalité, one of the Republic's pillars.
} 
which appeared more indirectly in my research, is that Morocco is a treaty country. This means that the immigrants can continue to lay claim to financial assistance from the Dutch or Belgian state, such as certain social security benefits entitlements and allowances. ${ }^{11}$ All these aspects make Morocco a popular hijra destination, which is reflected in a considerable presence of Dutch and Belgian Muslims living in different Moroccan cities across the country. These communities, with their networks, knowledge, and practical experience of the legal, religious, and emotional aspects of hijra to Morocco, again, draws in more muhajirun.

\section{Life in Morocco}

The Dutch and Flemish muhajirat are part of a wider group of Muslims from various European countries living in Morocco. The exact numbers are unknown, but I have met and heard about European Muslims men and women of diverse ethnic backgrounds from the age of 17 to 70 , with nationalities from France, Belgium, the Netherlands, Finland, Sweden, Spain, Ukraine, Germany, and the UK, living in various Moroccan towns and cities. The community entails European Muslims with an immigrant background born in a Muslim family, as well as converted "white" Muslims. ${ }^{12}$

For my interlocutors, settling in Morocco comes with ups and downs. On the one hand, many of the women indicated to be happy with their migration and cherish the Muslim normality they longed for. They no longer have to account for their religion and experience more elbowroom as a Muslim. The ease of walking around veiled and that acts of not shaking hands or not wanting to sit next to a man is more common practice than an exception in need of an explanation are considered large benefits of their migration. They can hear the call to prayer five times a day, they can eat everywhere, without having to worry whether the food is halal, and also the abundance of places where no alcohol is served is another much appreciated benefit. As Fatiha, a convert from the Netherlands, who lives in Tetouan with her family told me:

Here you go to the butcher and you can assume that all the meat is halal. It's like, the basic principles of Islam, they are understood and accepted by everyone, and people think it's a good thing when you hold yourself to those principles, or are engaged with them. ${ }^{13}$

Living in an environment in which being Muslim is the norm has stimulated many women to focus more on their religion and strengthened their faith and spiritual growth. This, in turn, sometimes leads to changing religious practices, such as the wearing of a niqab. At least two of my interlocutors started wearing a niqab after their migration to Morocco, while for others the problems they encountered in the Netherlands and Belgium because of wearing a niqab formed one of the reasons to consider hijra. Moreover, many women feel highly respected by the local population. Samira, a 23-

\footnotetext{
${ }^{11}$ These agreements were originally created as an incentive for Moroccan immigrants of the first generation in the Netherlands, to return to Morocco. https:/www.svb.nl/int/en/algemeen/verdragslanden.jsp

12 People of Anglo or European descent who convert to Islam are often referred to as "white" Muslims (Galonnier 2015).

${ }^{13}$ Interview with Fatiha, August 2018, Tetouan.
} 
year old divorced Belgian convert, living in Tangiers, told me how people in her neighborhood responded to her presence in public:

The man of the hanut (the local grocery), ( ... ), each time when I enter the shop ( ... ) he says "assalamu alaykum". [He] looks straight to the floor, [and] starts saying $d u^{\prime} a$ for me. [When] you are covered, men respect you enormously here ( ... ). ${ }^{14}$

Samira's quote illustrates that people in Morocco are generally very impressed when they witness converts practicing Islam (or second-generation Moroccans from Europe). They are amazed that people who grew up in the West, or are westerners themselves, are drawn to Islam and also diligently practice it. It often gains them a lot of compliments and admiration. This indicates that the converts' participation in Muslim normality and sociability becomes the basis on which they are valued and praised by locals, instead of rejected, as was the case in the homeland.

Another, rather profane, benefit of living in Morocco, mentioned by some of my interlocutors is the ability to live a much higher standard of life than in the home country. Compared to the Moroccan middle-class, they have a large volume of economic and cultural capital at their disposal. Some of the businesses set up by the husbands of the women were quite successful, generating a substantial income. ${ }^{15}$ This, in combination with the low cost of living, enables some of them to live a relatively prosperous life. They are able to afford spacious apartments or villas, in well-off suburbs, and sometimes have housekeepers (khadama) who help them with the household. They cohabitate in prosperous neighborhoods, with other muhajirat but also with other affluent groups (both Moroccan and non-Moroccan).

\section{Disappointment}

While some of them are happy with the material and spiritual aspects of life in Morocco, and even embrace part of the country's culture - such as learning to speak Moroccan Arabic (darija) and preparing Moroccan dishes - many of my interviewees also experienced feelings of disappointment. First of all, several converted muhajiarat indicated having experienced a culture shock. It is hard for them to connect to Moroccan culture and society because they feel they are "too Western." There is a large difference between the Netherlands and Belgium on the one hand, and Morocco on the other: there is more corruption, different standards of hygiene, and the Moroccan healthcare and schooling system are much lower in quality. Also, many converts indicate to have trouble with what they call "the Moroccan mentality." They complained about locals not being trustworthy or punctual, chaos in traffic, hypocrisy, double moral standards, bureaucracy, and materialism.

Many of my interlocutors believe that this Moroccan mentality is caused by a "lack of a true Islam" in Moroccan society. Moroccans are deemed to practice or promulgate an "incorrect" Islam. They would claim that Moroccan people are badly informed about

\footnotetext{
${ }^{14}$ Interview with Samira, June 2017, Tangiers.

${ }^{15}$ There are also economically less successful families who, due to financial problems, had to return. See article Vroon and Moors.
} 
matters of Islam, mostly because they would not know the difference between Islam and Moroccan culture (cf. Vroon \& Moors, this issue). In interviews, the muhajirat frequently presented Moroccan Muslim culture as a disturbance or deviation of a pure culture-free Islam (cf. Van Tilborgh 2009). As one of my interlocutors said: "People here say about much typical Moroccan things that it is Islamic, but it is not. They constantly confuse Islam and Moroccan culture." 16 In response, some converts try to propagate their own interpretation of Islam by "correcting" the local population in their religious practices and ideas, which often brings about much irritation and tensions on both sides.

With respect to this perception of Morocco as being an impious country, the women often accentuate the cultural values and practices of their home country when referring to a notion of a "true" Islam. In conversations, certain acts of behavior were mentioned as typically Dutch (or Flemish), such as honesty and directness, and related to Islamic ideals of conduct. For example, one of my interviewees stated: "Actually, if you look at the Dutch, people like my mother, in their behavior they are frankly more Muslim than the Muslims here." 17 This juxtaposition between a cultural Islam (which is deemed incorrect) and a "pure" Islam which is abstract and universal, is also present in their practices and narratives of the design and decoration of their domestic spaces.

\section{Home furnishing}

The homes of most of my interlocutors are situated in modern parts of urban areas, ${ }^{18}$ where they live in neighborhoods, compounds, and apartment complexes in the vicinity of other muhajirun. Most of them primarily adopt a role of housewife and mother, while their husband earns a living outside of the home. Some of them also have a paid job, working from home (often as a practitioner of hijama ${ }^{19}$ ) and sometimes outside of the home (mostly in call centers). During conversations with my interlocutors, many of them put much emphasis on activities concerning their homes and households, such as preparing food, taking care of their children, and also home furnishing. Similar to Tanja, they invest a great deal in furnishing their homes according to their taste.

The type of design prevalent in Moroccan housing rather differs from how houses are built and set up in the Netherlands and Belgium. The North African architectural heritage, based on traditional, social, and spatial organization patterns, still permeates contemporary Moroccan house design (Brunzel and Duric 2012). The architectural shell accommodates a particular set-up of the domestic space common in Morocco: the Moroccan salon (salon marocain). There are almost always two sitting area's (one for guests and one for the nuclear family), often demarcated by lower walls placed in the common space. The sitting area's design enables the installation of a Moroccan salon, with enough space for seddari against the walls, and room for a carpet and low

\footnotetext{
${ }^{16}$ Interview with Fatiha. June 2017, Salé.

${ }^{17}$ Interview with Saskia. Rabat 10 August 2015.

${ }^{18} \mathrm{I}$ have not encountered any muhajirun who took up a residency in the traditional section (medina) of cities.

${ }^{19}$ Hijama is a wet cupping therapy, in which blood is drawn by vacuum from a small incision in the skin with the application of suction cups. The healing practice is used to treat a wide range of medical conditions and is mentioned in the Sunna and Hadith, where it is said that the Prophet used and recommended cupping for therapeutic purposes (Turaeva 2020: 669).
} 
occasional tables (on which tea and food can be served), as well as pre-carved plaster ceilings with designated areas to hang a suspended chandelier. This set-up is the basic fixed material, which the women equip and furnish to their taste.

Most of the homes I visited, had adopted a Moroccan salon, as the converts' husbands and children often expressed their desire to have one to receive and entertain their Moroccan social circles, such as neighbors, friends, and relatives. However, the set-up of a Moroccan salon was often combined with interior design styles from their home country. For example, next to a Moroccan salon, many women had installed a separate dining area with a dining table and kitchen chairs, something rare in the homes of most Moroccan families. Also, some women had put arm-chaired couches or European sofa's in the living rooms instead of seddari. Others had adopted a Moroccan salon with seddari, but had not implemented the concomitant habitual baroque style of furnishing. Instead they used a style fit to Western tastes, with some subtle elements of Moroccan folk aesthetics. For example, instead of the typical flamboyant draped curtains of heavy ornamented textiles, prevalent in many Moroccan homes, the converts would choose plain-colored, simple light lace curtains instead (Fig. 1). In combining traditional Moroccan interior styles with European trends, the material and colors of the fabrics, and floors (preference for laminate or wood) and carpets, were locally bought, and carefully picked to match with a modern and often minimalist design. These would often be combined with IKEA, or IKEA-like furniture ${ }^{20}$ or other household objects, imported from the home country. These objects are believed to be better in quality and testify of more taste. Also, memory objects (Marshall 2019), referring to their own cultural and personal background are placed in the interior, such as an inherited table from the parental house, a Delftware plate, a painting made by a relative, cups and plates with folkloric motives, a wooden shoe, a picture of a Dutch landscape, or children's books in Dutch (Figs. 2 and 3).

\section{Religious considerations}

In the furnishing practices of the domestic spaces, various intersecting sensibilities play a role, which reflect the women's multiple senses of belongings, as well as their religiosity. For example, the religiously sanctioned segregation of gender was applied to the physical structure of the domestic space. Two women in my research, had put up large and long curtains throughout the domestic space, which could be opened or closed to create separate spaces, protecting herself or her husband from unrelated guests from the opposite sex (muharam). Another convert showed me how she had put up screens on the roof terrace and the garden of the house so she could enjoy the outside space together with her children without intrusive looks by the neighbors. Also, there were no images and pictures of animate beings present in the rooms I was allowed in, except for images of nature, such as plants and flowers.

Following rulings in Islam against the creation and worshipping of representations of animated beings, the portrayal of such beings (humans or animals), whether in pictures or three-dimensional objects, are avoided in the domestic sphere (Grüber and

\footnotetext{
${ }^{20}$ Even though an IKEA store opened in Casablanca in 2016, the majority of my interlocutors prefer importing IKEA furniture from the home-country as they do not trust the quality of the furniture sold in Morocco. Also, they criticized the Moroccan IKEA for pricing items higher than in the European catalogue.
} 


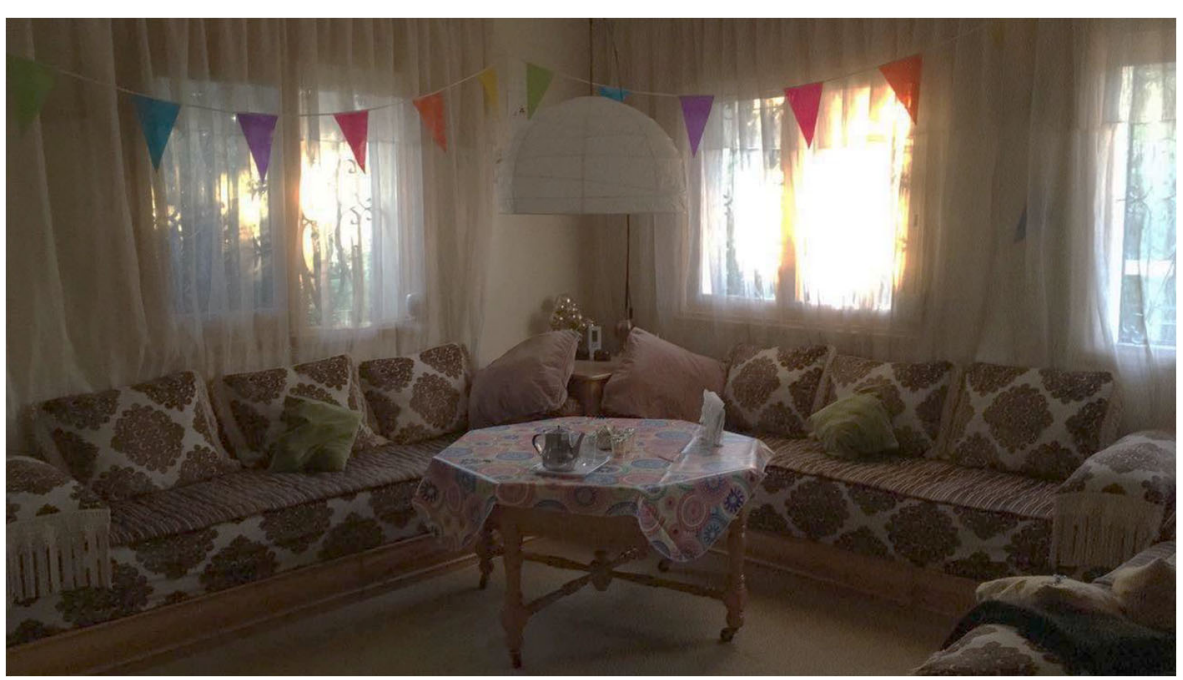

Fig. 1 A salon marocain of a Dutch convert living in Morocco, with IKEA lamp, simple lace curtains and birthday serpentines. CNina ter Laan, with courtesy of my interlocutor

Haugbolle 2013). A common narrative among the women is that such images chase away the angels, that write down and keep record of the prayers and good deeds of the people in the home. Notwithstanding, negotiations are made in this domain (cf. Walsham 2016). ${ }^{21}$ Family pictures for instance are present in most homes, but kept in places hidden away from sight, such as in boxes, drawers, smartphones, or closable cupboards. In some houses, I did notice figurative representations of animals and humans visibly present in the domestic space, but these figures were either very small without recognizable faces or the eyes would be covered, for instance with scotch tape (Fig. 3). The presence and organization of objects and images in the homes of the women, that are deemed potentially harmful are thus carefully managed (Meyer 2018). Their deliberate nonappearance is believed to mediate, or at least facilitate, the attraction and presence of spiritually beneficial energies and beings to the home, while simultaneously preventing the entering of potential harmful powers (Meyer 2012, 2015).

Some of the muhajirat in my study told me they examine and discuss Islamic rulings on images and objects in the home and their different interpretations by various Muslim scholars, as a filter through which they ethically assess various material forms and furnishing styles. For instance, some material forms are deemed recommended and even beneficial to their faith (such as open spaces, or hanging memory notes with $d u$ ' $a$ 's on doorposts giving access to particular rooms). There are also objects and images considered neutral and pose no threat, or objects and images which could potentially evoke particular unwanted sensibilities (particular sensual forms or materials), and those which are downright forbidden haram (images of animate beings, or provocative images of violence and sex). This deliberation process is not clear-cut, and

\footnotetext{
${ }^{21}$ Walsham has described the role of domestic artifacts in the reformation in the domestic space of Dutch protestants, who sometimes are portrayed as iconophobic, mark the home (Walsham 2016).
} 


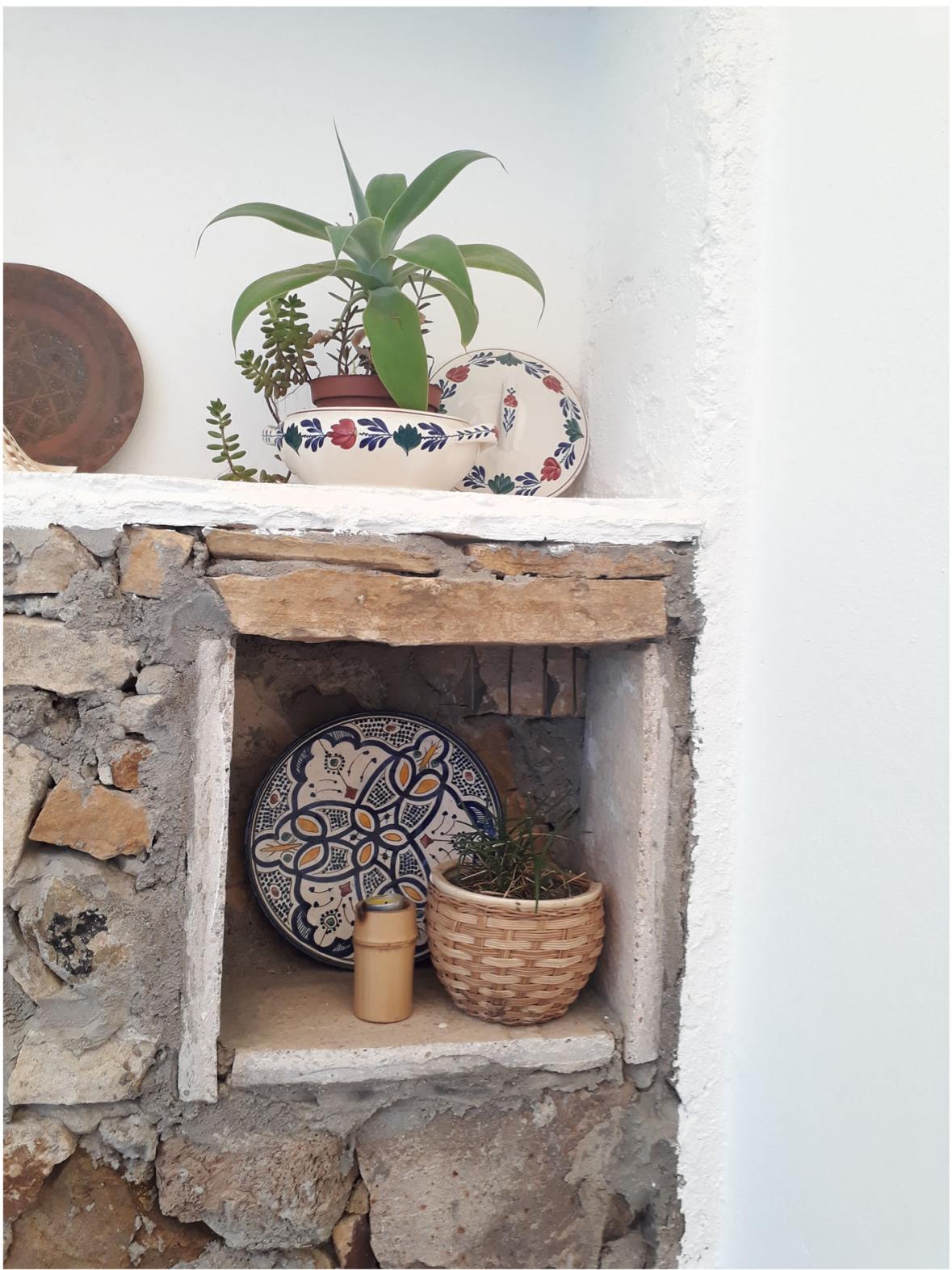

Fig. 2 Outdoor cabinet in the garden of a Dutch convert. On top of the cabinet stands an earthenware soup bowl, used as a plant pot, with traditional Dutch farmers' folkloric motives, called "Boerenbont." On the shelf below, a traditional Moroccan plate is placed, embellished with typical pattern designs. (ONina ter Laan, with courtesy of my interlocutor

involves adaptations, compromises, sacrifices, and negotiations. While some Moroccan traditions are rejected as un-Islamic, such as the hanging of Quranic verses on the wall, other local furnishing practices are embraced and incorporated into the interior setting, and combined with personal style preferences, culturally influenced tastes, and interior design trends, which are integrated into 


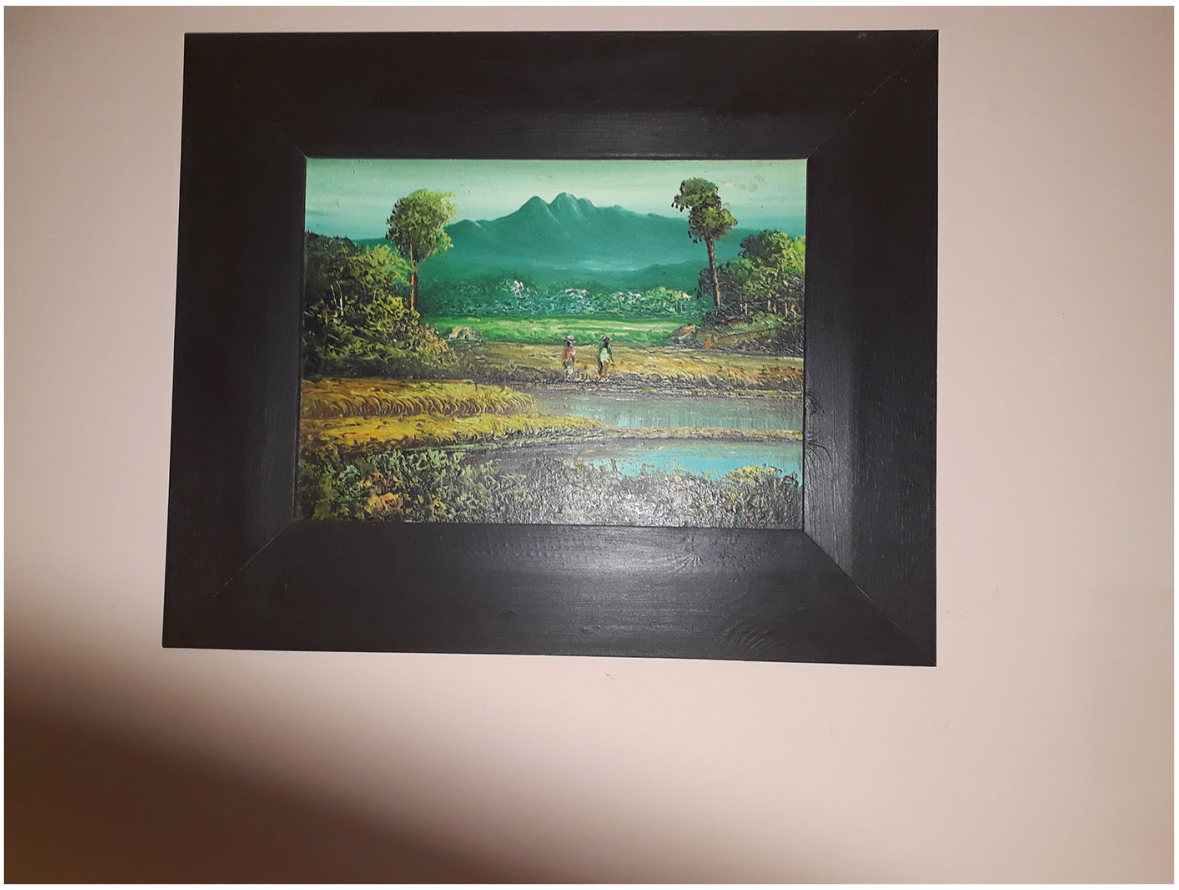

Fig. 3 A painting on the wall in the Moroccan home of a Dutch convert. The painting represents her connection to Indonesia. The figures in the painting have no recognizable faces. CNina ter Laan, with courtesy of my interlocutor

their articulation of Islamic ideals. This often results in an interior décor characterized by austere and sober aesthetics.

\section{Matters of piety and sobriety}

Compared to their Moroccan counterparts, the converts' domestic spaces are generally characterized by simplicity, functionality, and sobriety, which is reflected in an inclination toward simple lines (instead of an overload of ornate curved forms), matching neutral plain colors, such as beige and white, or terracotta and brown, combined with natural textures and materials. Also, in most of the homes I visited, IKEA modernism seemed to be the most popular trend. The preference for minimalist aesthetics, such as in the Scandinavian style of IKEA, characterized by simplicity, open spaces, and functionality, fits Islamic ideals of purity and modesty (Fig. 4). As Souhaila, a Flemish convert living in a compound in Tangiers, inhabited by mainly muharijrun from Europe, told me:

[I] think the keyword here is IKEA. Everyone here just has the same interior ( ...) [because] one just feels at home in one's own environment (...) and we remain Western of course. I mean (...) we are born in Belgium, yes, I am converted now, but there are other sisters who are born in Belgium (...) [with] a Moroccan 


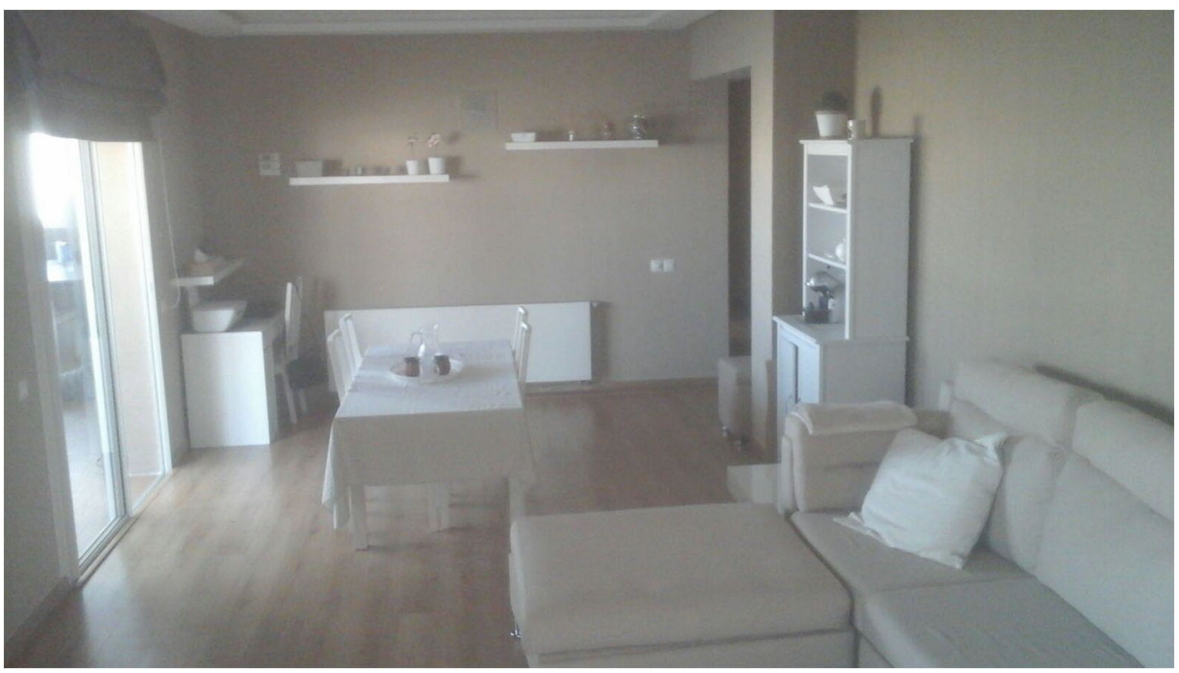

Fig. 4 A domestic space of a convert from Belgium, characterized by aesthetic minimalism. (C) Nina ter Laan, with courtesy of my interlocutor

background, but we all grew up Western of course. And I think that that is one of the only things in which religion does not play a role, I mean our religion does not impose us to have a Moroccan seddari, for example (...) but at [the homes of] most of the muhajirun, that I have visited [here], (...) [the] interior design is quite austere (...)We (she and other muhijarat) are all huge fans of IKEA, but it (the interior design) is also very simple at our homes (...) and yes, that [actually] has to do with religion, no pictures on the wall of course (...), not too much decoration and such (...). Those are the things in which you can notice the difference between us [muhijarat from Europe] and the traditional people from Morocco (...) they are very focused on decoration. We have less of that. ${ }^{22}$

Souhaila's remark at first seems contradictory. She states that the interior design is the one thing which has nothing to do with religion, but then comes back from her statement, by saying it does have to do with religion, as it radiates soberness and austerity. This sober style of aesthetic minimalism converges with Islamic principles, rulings, and prescripts on the creation of an Islam-approved dwelling. As such, mundane material objects, such as IKEA furniture becomes "re-signified" as religiously meaningful due to its sobriety, which in her reading of Islam enhances piety. However, there is more.

Souhaila's description of domestic decoration among muhajirat inherently rejects traditional Moroccan styles of interior design. Her phrase: "They are very focused on decoration. We have less of that," at first seems to be mostly a judgment of taste, yet it also reads as an indirect moral critique, shared by most of my interlocutors, of Moroccans being less religious. This indicates how the (selective) embrace of minimalist aesthetics, and the rejection of ornate Moroccan interior decors, is intertwined with broader narratives of religious (im)perfection. Although the majority of my interviewees implement the basics of a Moroccan salon, they reject the quasi-

$\overline{22}$ Interview with Souhaila. Tangiers, 17 June 2017. 
aristocratic style of furnishing still prevalent in many Moroccan homes. Elements such as bold color combinations, excessively bright lighting, curvy motives, fringes, golden ridges, thick and layered jacquard-style draped curtains, and shiny nylon fabrics with patterned designs, are seen as too extravagant, vulgar, distasteful, unpractical, and unnecessary kitschy "tierelantijntjes" (frills), but also as un-Islamic. For instance, hanging calligraphy of the names of Allah or Quranic verses on the wall, especially in colorful brocade and gold colored frames, which many Moroccan families do in order to protect their house and family, is considered inappropriate by most of my interlocutors as it could lead to shirk (idolatry). Tastes and preferences in furnishing practices thus create a sense of distinctive community among the converts, as well as produce differences regarding Moroccan society. Moral judgments are attached to these differences, through which many white muhajirat tend to place themselves higher in a moral and religious hierarchy, above local Moroccans.

In addition to a setting where the muhajirat express and enhance their faith, the domestic space is also an arena in which feelings of disappointment with Morocco as a Muslim country and unfulfilled feelings of longing for a religious environment are regulated. The literature on "Islam and everyday life" (Schielke 2010; Fadil and Fernando 2015) and on religious failure (Beekers and Kloos 2017) might be helpful here, yet is simultaneously insufficient to grasp the feelings of disappointment these muhajirat experience. Studies foregrounding "everyday Islam," which emerged as a critical response to an overemphasis on piety and ethical norms in anthropological studies of Islam, emphasized the ambivalences and contingencies involved in the striving toward religious perfection. However, these works mostly focus on the shortcomings the worshippers observe within themselves. In the case of my study, it is rather the religious imperfection of others that my interlocutors struggle with and which some perceive as a barrier in the development of their own piety. Rather, my interlocutors expressing feelings of moral superiority toward the "uncommitted" Islamic character of their fellow Moroccan Muslims indicates that their personal striving and authentication of an ever-evolving pious self (Deeb 2006; Mahmood 2005), their desire for a religious utopia (Johnson 2006), and its unsatisfactory realization in the Moroccan context, also rests on mechanisms of distinction (Bourdieu 1984).

Furthermore, as pointed out by Fadil and Fernando, studies with a focus on "everyday Islam" contributed to a tendency of seeing everyday life in opposition to and separate from religious life, reiterating underlying divisions between the secular and the religious (Fadil and Fernando 2015). My study shows, however, that the women's taste preferences in domestic decoration form an integral part of their cultivation of a pious self. The furnishing of their homes is not only meant to make their domestic space comforting and inviting, but also to generate a religious atmosphere, which enhances piety. As such, instead of opposing everyday- and religious life, my analysis of home furnishing and domestic decoration as tools to enhance piety contributes to scholarly efforts to think of piety and the everyday together, instead of apart (Deeb 2015). 


\section{Issues of taste and Europeanness}

The generation of a Muslim atmosphere through the incorporation of mundane material objects contributes to ethical self-making, but these objects and materials also indicate taste and distinction in the post-colonial context of Morocco.

The relative wealth of the white muhajirat, combined with their geographical, economic, and symbolic proximity to Europe, together with the relative low cost of living in Morocco, not only allows them to perpetuate the middle-class consumer lifestyle most of them were used to back home, but also to elevate their social status. The middle-class lifestyle they were used to gives them access to an upper-class style of living and status in Morocco. IKEA furniture, for example, once meant as affordable and accessible designer products for European middle-class consumers, are luxury products in Morocco, only consumed by the upper class, because of its price tag, as well as its strong association with Europe and Western modernity, and as such bring status (e.g., Erdei 2014). While engaging in the homemaking practices I described above, they thus also perform "Europeanness," which, combined with their ethnicity, in Morocco grants them upper-class status.

The Moroccan context is important here. Morocco is an Islamic monarchy, with a colonial past, where different racial hierarchies were at stake, which were layered and intersected with cultural, religious, linguistic, and class distinctions. During the time of the Spanish and French Protectorate, these different social (often porous) boundaries helped to keep the colonial hierarchy in place. Even though the French and Spanish occupiers always worked together with Moroccans in its administration, Moroccans were generally seen as inferior to them, and to Europe in general, which was the symbol of colonialism and power (Calderwood 2018). The concept of "Europeanness," stood at the center of this colonial hierarchy (Luttikhuis 2013). In the context of colonial divide-and conquer policies, boundaries were constructed between and within groups by placing some in closer proximity to Europe than others. Berber (Amazigh) tribes, for instance, were believed to be of European ancestry and also less fanatical in their religious beliefs, than the Moroccan Arabs (cf. Hart 2000).

Such colonial pasts, according to Ann Stoler, "continue to carve out the environmental and psychic debris in which people live, long after colonial polities have been dismantled" (Stoler 2010: xviii). In Morocco, "Europeanness" remains a marker of privilege and social prestige. This category is determined by "whiteness," but as a social category, which is co-determined by class, heritage, language, religious orientation, and culture. The transnational circulation of modern minimalist aesthetics, popular in contemporary Europe, among white converts in Morocco thus taps into powerful and contested local postcolonial discourses of "Europeanness" (Mankekar 2002: 92). This makes the consumption of products and styles of European interior design into highly valuable cultural and symbolic capital and a marker of Europeanness. These kinds of products and styles are not only sought after by white converts, but by many others living in Morocco, including European-Moroccan muhajirat, as well as Moroccan elites from the (secular) upper class, who (seek to) acquire Europeanness, by adopting a modern Western lifestyle. Their religiously inspired migration to a Muslim country is thus also a relocation to a non-Western postcolonial setting, which allows them to restore some of the privileges they lost upon their conversion in the home land. 


\section{An Islam of the Low Countries in Morocco?}

The critical engagement of my interlocutors with images and objects in their domestic spaces resonates with Tweed's "kinetics of homemaking" (1997). Where he attributes active influence of material culture to the inner disposition of believers, the muhajirat design their interiors through careful deliberation of what objects and images are religiously allowed in the domestic space and how these express but also may shape their pious selves. In this process, they incorporate and combine different interior styles and material forms to generate an atmosphere that enhances Muslim piety and "turns secular things into religious items" (Moors 2012: 277). Such practices of everyday material piety have also been described in literature on Islamic piety and consumption, such as studies on Islamic fashion, where new forms of Islamic dress incorporate Western aesthetics and are being re-signified as compatible with Islam (Lewis 2015). In the case of my study, IKEA furniture, for instance, becomes "re-signified" as religiously meaningful due to its sobriety.

Sobriety is not only expressed through material forms with austere qualities but also through immaterial forms. Following the art-historical research of Victoria George (2012) and William Dyrness (2019) on protestant aesthetics, I conceptualize open spaces, lack of images, plain colors, or barren walls as more than iconoclast removals of materiality. Such immaterial forms should be considered as aesthetic and religiously meaningful elements in their own right, as much as the tactile and visible objects placed in the domestic space, where they act in concert to stimulate piety and spiritual transformation.

My interlocutors' preference for aesthetic minimalism, does not only demonstrate a convergence of taste with religious considerations but also reveals a distinctive "culturalized" Islam of the Low Countries (Flanders and the Netherlands), with a modernist and maybe even a protestant inclination. In my ethnographic accounts, the white Dutch and Flemish Muslim emigrants juxtapose their own reading of Islam as pure, universal and "deculturalized," against a Moroccan "culturalized" Islam. However, at the same time, they combine different cultural systems and moral frameworks of being Muslim and Dutch or Flemish themselves. So even though the muhajirat claim to adhere to a pure "culture-free" Islam (Vroon-Najem 2019; Van Tilborgh 2009); their interpretation of Islam is just as well "imbued with cultural values and liberal-secular sensibilities upheld by bodily practices and emotional attachments" (Scheers et al. 2019). These sensibilities, such as simplicity, functionality, utility, self-restraint, and sobriety hint at the cultural sediments of protestant Christianity (Verrips 2006), and become apparent as they jostle against the local cultural and religious sensibilities of their fellow Moroccan Muslims.

This outcome contradicts the dominant perception that Islam conflicts with European liberal values and lifestyles (Olsson 2014). The clashing of tastes and religious sensibilities regarding decorating practices of Dutch and Flemish white converts with those of Moroccan Muslims, puts ideas of a Euro-Islam in a new and different light. Whereas previous discussions on Euro-Islam (Césary 2014) mainly have focused on the integration of Islam into European cultures, my research material indicates that Islam in Europe has evolved along and is integrated with distinctive different European national cultural practices and sensibilities. 
More broadly, the home furnishing of my interlocutors shows that piety is not developed next to, but as an inherent part of the pragmatic sensibilities of everyday life (Deeb 2015; Tweed 1997). Theorizing the everyday as an intrinsic and inseparable element in the formation of an ethical self, further contributes to efforts in the ongoing debate on "everyday Islam" to think of piety and the everyday together. It also calls for a more integrative approach of research and analysis. Lastly, my interlocutors' deliberate use of empty spaces, voids, and invisibility, in the furnishing of their homes, as elements interacting with material forms to generate a religious atmosphere, also calls for the further investigation of immaterial forms in the material study of religion.

\section{Conclusion}

For the Dutch and Flemish women in my study, their emigration to Morocco is an attempt to realize an Islamic dream (home) away from home with the purpose of freely practicing their faith and strengthening their iman (faith). This desire is validated in and emerges from theological argumentation, which allows them to withdraw from stigmatizations of Muslims and Islam in their societies. In practicing hijra, "home" becomes the space, practice, and the imagined idyll, where the alienation and discomfort of not-belonging might be undone. In this sense, the religious emigration to Morocco can be seen both as an act of piety and resistance to European Islamophobia. However, moving to a Muslim country, in this case Morocco, does not automatically give them a sense of home. They are faced with a culture shock and disappointment regarding a perceived lack of religiosity in the country. Their cultural and religious sensibilities differ from those of their fellow Moroccan Muslims. This is reflected in my interlocutors' narratives and practices of home furnishing.

In their decorating practices of the domestic space, the Dutch and Flemish muhajirat articulate their search for religious purity as well as various overlapping and conflicting senses of belonging. They underline ascetic functionality and simplicity through the use of sober and austere material forms but also through "immateriality," such as open spaces and empty walls. This, in combination with personal memory objects, is arranged in such a way as to create a sensory environment, which generates a religious atmosphere. These aesthetic regimes are meant to enhance the formation of a distinct Muslim ethical self, that incorporate mundane material forms and a taste preference for minimalistic design, such as IKEA. These taste preferences jostle against local cultural and religious sensibilities: disapproval and disdain were expressed regarding the more baroque Moroccan furnishing styles, which they rejected as vulgar, "other," and un-Islamic. Their tastes and preferences are not only incorporated in their endeavor to become "authentic" Muslims but also tie into the cultural capital of a "colonial field" of Moroccan society, where a preference for European/Western aesthetics are distinctive signs of social prestige and Europeanness. The converts thus perform a "culturalized" West-European Islam in Morocco, which intersect with mechanisms of distinction that also refer to other models of being, such as class and "Europeanness."

Acknowledgements My sincere gratitude goes out to all of my interlocutors, who have shared with me their stories and let me into their homes. I would also like to offer my warm thanks to Birgit Meyer and Marieke 
Slootman whose suggestions helped improve and clarify this manuscript. Earlier versions of this article were discussed during the 'Leaving Europe' conference in Leuven and the 'Hijra as Migration' workshop in Amsterdam, where colleagues provided constructive criticisms. I particularly want to thank Nadia Fadil and Annelies Moors for their insightful comments after reading various drafts. Finally, I would like to acknowledge the two anonymous reviewers of Contemporary Islam for their helpful feedback.

Funding This article is an outcome of a broader ethnographic research project on home-making practices among white Dutch and Flemish female Muslim converts in Morocco. The research project is part of the research program Religious Matters in an Entangled World (www.religiousmatters.nl), led by Prof. dr. Birgit Meyer, conducted at Utrecht University the Netherlands, and funded by the Royal Netherlands Academy of Arts and Sciences (KNAW) and The Netherlands Foundation for Scientific Research (NWO).

Open Access This article is licensed under a Creative Commons Attribution 4.0 International License, which permits use, sharing, adaptation, distribution and reproduction in any medium or format, as long as you give appropriate credit to the original author(s) and the source, provide a link to the Creative Commons licence, and indicate if changes were made. The images or other third party material in this article are included in the article's Creative Commons licence, unless indicated otherwise in a credit line to the material. If material is not included in the article's Creative Commons licence and your intended use is not permitted by statutory regulation or exceeds the permitted use, you will need to obtain permission directly from the copyright holder. To view a copy of this licence, visit http://creativecommons.org/licenses/by/4.0/.

\section{References}

Ahmed, S. (1999). Home and away: Narratives of migration and estrangement. International Journal of Cultural Studies, 2(3), 329-347.

Appadurai, A. (1996). Modernity at large: Cultural dimensions of globalization. Minneapolis: University of Minnesota Press.

Beekers, D., \& Kloos, D. (Eds.). (2017). Straying from the straight path. How senses of failure invigorate lived religion. Oxford: Berghahn.

Berger, M. S. (2014). A brief history of islam in Europe. In Thirteen centuries of creed, conflict and coexistence. Leiden: Leiden University Press.

Berriane, M., De Haas, H., \& Natter, K. (Eds.). (2016). Revisiting Moroccan migrations. New York: Routledge.

Bhabha, H. K. (1994). The location of culture. London: Routledge.

Bilecen, B. (2017). Home-making practices and social protection across borders: An example of Turkish migrants living in Germany. Journal of Housing and the Built Environment, 32(1), 77-90.

Bleich, E. (2011). What is islamophobia and how much is there? Theorizing and measuring an emerging comparative concept. American Behavioral Scientist, 55(12), 1581-1600.

Bourdieu, P. (1984). Distinction: A social critique of the judgement of taste. London: Routledge.

Boccagni, P. (2017). Migration and the search for home: Mapping domestic space in migrants' everyday lives. New York: Palgrave.

Brunzel, T. \& S. Duric (2012). Moroccan architecture, traditional and modern - a field study in Casablanca, Morocco. LTH School of Engineering, Lund University. BA-thesis.

Calderwood, E. (2018). Colonial al-Andalus: Spain and the making of modern Moroccan culture. Cambridge: Harvard University Press.

Cath, C. J. N. (2011). Aliyah and the ingathering of exiles: Jewish immigration to Israel. Cultural Anthropology, Utrecht University. BAthesis.

Césary, J. (Ed.). (2014). The Oxford Handbook of European Islam. Oxford: Oxford University Press.

Cottaar, A., Bouras, N. \& Laouikili, F. (2009). Marokkanen in Nederland. De pioniers vertellen. Amsterdam: Meulenhoff.

Cieraad, I. (2017) 'Home'. International encyclopedia of anthropology. Hoboken: Wiley-Blackwell.

De Bree, J., Storms, O., \& Bartels, A. (2011). In between The Netherlands and Morocco: 'Home' and belonging of Dutch Moroccan return migrant and abandoned children in Northeast Morocco. In S. J. T. M. Evers, C. Notermans, \& E. Van Ommering (Eds.), Not just a victim: The child as catalyst and witness of contemporary Africa (pp. 173-197). Leiden: Brill.

De Caigny, S. (2005). Catholicism and the domestic sphere: working-class women in inter-war Flanders. Home Cultures, 1, 1-24. 
de Koning, M. (2008). Zoeken naar een zuivere Islam. Identiteitsvorming en geloofsbeleving van jonge Marokkaans-Nederlandse moslims (Doctoral thesis, Vrije Universiteit, Amsterdam, the Netherlands). Retrieved from https://research.vu.nl/en/publications/zoeken-naar-een-zuivere-islamgeloofsbeleving-enidentiteitsvormi.

de Koning, M. (2013). The moral maze: Dutch salafis and the construction of a moral community of the faithful. Contemporary Islam: Dynamics of Muslim Life, 7(1), 71-83.

de Koning, M. (2016a). "You need to present a counter-message." The racialisation of Dutch Muslims and anti-Islamophobia initiatives. Journal of Muslims in Europe, 5(2), 170-189.

de Koning, M. (2016b). Understanding Dutch Islam. Exploring the relationship of Muslims with the State and the public sphere in the Netherlands. In H. Moghissi \& H. Ghorashi (Eds.), Muslim diaspora in the west: Negotiating gender, home and belonging (pp. 181-196). New York: Taylor \& Francis.

de Koning, M. (2019). Vijf mythen over islamofobie. Kif Kif: Yunus Publising.

Deeb, L. (2006). An enchanted modern: Gender and public piety in Shi'i Lebanon. Princeton: Princeton University Press.

Deeb, L. (2015). Thinking piety and the everyday together. A response to Fadil and Fernando. HAU: Journal of Ethnographic Theory, 2(5), 93-96.

Dibbits, H. \& H. van der Horst (2007) Turkse en Marokkaanse Nederlanders thuis. Amsterdam: Amsterdam University Press

Duyvendak, J. W. (2011). The politics of home: Belonging and nostalgia in Europe and the United States. Basingstoke: Palgrave MacMillan.

Dyrness, W. (2019). The origins of protestant aesthetics in early modern Europe: Calvin's reformation poetics. Cambridge: Cambridge University Press.

Erdei, I. (2014). IKEA in Serbia debates on modernity, culture and democracy in the pre-accession period. In Mirroring Europe ideas of Europe and Europeanization in Balkan societies (pp. 114-134). Leiden: Brill.

Fadil, N. (2014). Islam and feminism: A vexed relationship? Thinking through the "Muslim question" and its epistemological conundrums. DiGeSt. Journal of Diversity and Gender Studies, 1(1), 51-59.

Fadil, N., \& Fernando, M. L. (2015). Rediscovering the "everyday" Muslim: Notes on an anthropological divide. HAU: Journal of Ethnographic Theory, 2(5), 59-88.

Fernando, M. L. (2014). The Republic unsettled: Muslim French and the contradictions of secularism. Durham: Duke University Press.

Galonnier, J. (2015). The racialization of Muslims in France and the United States: Some insights from white converts to Islam. Social Compass, 62(4), 570-583.

George, V. (2012). Whitewash and the New Aesthetic of the Protestant Reformation. London: Pindar Press.

Ghage, H. (1997). At home in the entrails of the west: multiculturalism, ethnic food and migrant home-building In: Home/ world: space, community and marginality in Sydney's West (pp. 99-153). London: Pluto Press.

Gould, H. (2019). Domesticating Buddha: Making a place for Japanese Buddhist altars (Butsudan) in Western homes. Material Religion, 15(4), 488-510.

Grüber, C.J., \& S. Haugbolle (2013). Visual culture in the modern Middle East: rhetoric of the image. Ebook.

Hall, S. (1990). Cultural identity and diaspora. In J. Rutherford (Ed.), Identity: community, culture, difference. London: Lawrence \& Wishart.

Hart, D. M. (2002). Tribe and Society in Rural Morocco. London: Frank Cass Publishers.

Hart, D. M. (2000). Tribe and Society in Rural Morocco. London: Frank Cass Publishers.

Hirschkind, C. (2006). The ethical soundscape: Cassette sermons and Islamic counterpublics. New York: Columbia University Press.

Hooks, B. (2009). Belonging: A culture of place. New York: Routledge.

Jackson, M. (1995). At home in the world. Durham: Duke University Press.

Jaffe, R., \& Koning, A. (2016). Introducing urban anthropology. New York: Routledge.

Jansen, S., \& Löfving, S. (Eds.). (2009). Struggles for home: Violence, hope and the movement of people. London: Berghahn Books.

Johnson, P. (2006). Unravelling Foucault's 'different spaces. History of the Human Sciences, 19(4), 75-90.

Jouili, J. (2015). Pious practice and secular constraints: Women in the Islamic revival in Europe. Stanford: Stanford University Press.

Keane, W. (2008). On the materiality of religion. Material Religion, 4(2), 230-231.

Kiefer, P.W. (2019). Renegado: Immigrant identities and aspirations of white Muslim converts in Morocco. Independent Study Project (ISP) Collection SIT.

Kruse, C., Meyer, B., \& Korte, A. M. (Eds.). (2018). Taking offense: Religion, art and visual culture in plural configurations. Paderborn: Wilhelm Fink Verlag.

Lewis, R. (2015). Muslim fashion. Contemporary style cultures. Durham: Duke University Press. 
Luttikhuis, B. (2013). Beyond race: constructions of "Europeanness" in late-colonial legal practice in the Dutch East Indies. European Review of History, 20(4), 539-558.

Mahmood, S. (2005). Politics of piety: The Islamic revival and the feminist subject. Princeton: Princeton University Press.

Mallet, S. (2004). Understanding home: a critical review of the literature In. Sociological Review, 52(1), 63-89.

Mankekar, P. (2002). 'India shopping': Indian grocery stores and transnational configurations of belonging. Ethnos, 67(1), 75-97.

Marshall, S. (2019). Memory objects': Material objects and memories of home in the context of intra-African mobility. Journal of Material Culture, 24(3), 253-269.

Margry, P. J. (2011). Practicing Religion in Private: The Home Altar. In P. Post (Ed.), Sacred places in modern Western culture (pp. 227-233). Leuven: Peeters.

Massey, D. (2005). For Space. London: Sage Publishing.

Meyer, B. (Ed.). (2010). Aesthetic formations: Media, religion, and the senses. New York: Palgrave Macmillan.

Meyer, B. (Ed.). (2012). Mediation and the genesis of presence. Towards a material approach to religion. Inaugural Lecture, Utrecht University, October 19.

Meyer, B. (2015). Picturing the Invisible: Visual Culture and the Study of Religion. Method \& Theory in the Study of Religion, 27(4-5), 333-360.

Meyer, B. (Ed.). (2018). Frontier zones and the study of religion. Journal for the Study of Religion, 31(2), 57-78.

Miller, D. (1988). Miller, D. (1988) 'Appropriating the State on the Council Estate. Man, 23, 353-372.

Mitiche, A. Z. (2019). From colonial divide et impera to the war on terror: A case study on the racialized Muslim subject in Morocco [Paper presentation]. Middle East Studies Association: 53rd Annual Meeting, New Orleans, LA.

Morgan, D. (Ed.). (2010). Religion and material culture: The matter of belief. New York: Routledge.

Moors, A. (2009). The Dutch and the face-veil: The politics of discomfort. Social Anthropology, 14(4), 393-408.

Moors, A. (2012). Transgressing the religious-secular divide? Material Religion, 8(3), 399.

Moosavi, L. (2015). The racialization of Muslim converts in Britain and their experiences of Islamophobia. Critical Sociology, 41(1), 41-56.

Navest, A., De Koning, M., \& Moors, A. (2016). Chatting about marriage with female migrants to Syria: Agency beyond the victim versus activist paradigm. Anthropology Today, 32(2), 22-25.

Nelson, J. K. (2008). Household Altars in Contemporary Japan: Rectifying Buddhist “Ancestor Worship" with Home Decor and Consumer Choice. Japanese Journal of Religious Studies, 35(2), 305-330.

Nieuwkerk, K. van (2004). 'Veils and wooden clogs don't go together.' Ethnos, 69(2), 229-246.

Noor, S. (2018). Creating a female Islamic space piety, Islamic knowledge and religious authority among born-Muslims and converts to Islam in the Netherlands and Belgium (Unpublished doctoral thesis). Radboud University, Nijmegen, the Netherlands.

Nowicka. (2007). Mobile locations: construction of home in a group of mobile transnational professionals. Global Networks, 7(1), 69-86.

Olsson, S. (2014). Swedish puritan Salafism: A hijra within. Comparative Islamic Studies, 8(1-2), 71-92.

Özyürek, E. (2015). Being German, becoming Muslim: Race, religion, and conversion in the new Europe. Princeton: Princeton University Press.

Rogozen-Soltar, M. (2012). Managing Muslim visibility: Conversion, immigration, and Spanish imaginaries of Islam. American Anthropologist, 114(4), 611-623.

Roex, I., van Stiphout, S., \& Tillie, J. (2010). Salafisme in Nederland: aard, omvang en dreiging. Amsterdam: Instituut voor Migratie- en Etnische Studies.

Said, E. (1978). Orientalism. New York: Vintage books.

Samanani, J., \& Lenhard, F. (Eds.). (2019). Home. Ethnographic encounters. London: Bloomsbury.

Sandu, A. (2013). Transnational homemaking practices: Identity. Belonging and Informal Learning, Journal of Contemporary European Studies, 21(4), 496-512.

Scheers, M., Fadil, N., \& Schepelern Johansen, B. (2019). Secular bodies, affects and emotions European configurations. London: Bloomsbury.

Schielke, S. (2010) Second thoughts about the anthropology of Islam, or how to make sense of grand schemes in everyday life. (ZMO Working Papers, 2). Berlin: Z.M.O.

Schinkel, W. (2008) The Moralisation of Citizenship in Dutch Integration Discourse. Amsterdam Law Forum, 1(1), http://amsterdamlawforum.org/article/view/56/77.

Stoler, A. L. (2010). Carnal knowledge and imperial power. Race and the intimate in colonial rule. Berkeley: University of California Press.

Swierenga, R. P. (2000). Faith and family: Dutch immigration and settlement in the United States, 1820-1920. New York and London: Holmes \& Meier. 
Turaeva, R. (2020). Muslim orders in Russia: Trade networks and hijama healing. Nationality Papers, 48(4), 661674.

Tweed, T. A. (1997). Our Lady of the Exile: Diasporic Religion at a Cuban Catholic Shrine in Miami. New York: Oxford University Press.

Tweed, T. A. (2006). Crossing and dwelling: A theory of religion. Cambridge: Harvard University Press.

Uberman, M., \& Shay, S. (2016). Hijrah According to the Islamic State: An Analysis of Dabiq. Counter Terrorist Trends and Analysis, 8(9), 16-20.

van Es, M. A. (2019). Muslim women as 'ambassadors' of Islam: Breaking stereotypes in everyday life. Identities, 26(4), 375-392.

van Nieuwkerk, K. (2006). Introduction. Gender and conversion to Islam in the West. In K. van Nieuwkerk (Ed.), Women Embracing Islam (pp. 1-16). Austin: University of Texas Press.

van Tilborgh, Y. (2009). Het islamdebat en de strategische emoties van moslima's. In Jaarboek Kennis Samenleving: Gevoel voor kennis (pp. 98-120). Amsterdam: Uitgeverij Aksant.

Verrips, J. (2006). Ottolandse onderzoekservaringen. In de marge, 15(3), 20-25.

Vroon-Najem, V. (2014). Sisters in Islam: women's conversion and the politics of belonging: A Dutch case study. Amsterdam: Universiteit van Amsterdam.

Vroon-Najem, V. (2019). Muslim converts in the Netherlands and the quest for a "culture-free" Islam. Archives de sciences sociales des religions, 186, 33-51.

Wagenmakers, J. (2016) Salafism. Oxford Research Encyclopedia of Religion. Oxford University Press.

Walsham, A. (2016). Domesticating the reformation: Material culture, memory, and confessional identity in early modern England. Renaissance Quarterly, 69(2), 566-616.

Wilson, R. \& W. Dissanayake (1996) Global/local: Cultural production and the transnational imaginary. Durham: Duke University Press.

Young, I. M. (2005). House and home: Feminist variations on a theme. In I. M. Young (Ed.), On female body experience: Throwing like a girl and other essays (pp. 123-154). Oxford: Oxford University Press.

Yuval-Davis, N. (2011). The politics of belonging. Intersectional contestations. London: Sage Publishing.

Publisher's note Springer Nature remains neutral with regard to jurisdictional claims in published maps and institutional affiliations. 